\title{
Wine as a Cultural Product Symbolic Capital and Price Formation in the Wine Field
}

\author{
Beckert, J ; Rössel, Jörg ; Schenk, Patrick
}

\begin{abstract}
In markets for goods that are valued for their aesthetic qualities, the ascription of value appears to be an uncertain social process. The wine market is an extraordinary example, as most persons are not able to differentiate between wines based on objective sensory characteristics. Therefore, we theorize valuation according to Bourdieu's field theoretical perspective as a social process in which quality is contested. Our empirical analysis shows, first, that his model has considerable power in explaining price differentiation between wineries and second, that the orientation of consumers toward different segments of the field is based on a homologous class hierarchy.
\end{abstract}

DOI: https://doi.org/10.1177/0731121416629994

Posted at the Zurich Open Repository and Archive, University of Zurich ZORA URL: https://doi.org/10.5167/uzh-135413

Journal Article

Originally published at:

Beckert, J; Rössel, Jörg; Schenk, Patrick (2017). Wine as a Cultural Product Symbolic Capital and Price Formation in the Wine Field. Sociological Perspectives, 60(1):206-222.

DOI: https://doi.org/10.1177/0731121416629994 


\title{
Wine as a Cultural Product: Symbolic Capital and Price Formation in the Wine Field
}

Sociological Perspectives 2017, Vol. 60(I) 206-222 (C) The Author(s) 2016 Reprints and permissions: sagepub.com/journalsPermissions.nav DOI: $10.1177 / 0731121416629994$ journals.sagepub.com/home/spx

@SAGE

\author{
Jens Beckert', Jörg Rössel², and Patrick Schenk ${ }^{2}$
}

\begin{abstract}
In markets for goods that are valued for their aesthetic qualities, the ascription of value appears to be an uncertain social process. The wine market is an extraordinary example, as most persons are not able to differentiate between wines based on objective sensory characteristics. Therefore, we theorize valuation according to Bourdieu's field theoretical perspective as a social process in which quality is contested. Our empirical analysis shows, first, that his model has considerable power in explaining price differentiation between wineries and second, that the orientation of consumers toward different segments of the field is based on a homologous class hierarchy.
\end{abstract}

\section{Keywords}

wine, economic sociology, Bourdieu, field, class, price

\section{Introduction}

Understanding the valuation of goods in markets has become one of the key topics in economic sociology in recent years (Beckert and Aspers 2011; Beckert and Musselin 2013; Beckert and Rössel 2013; Callon, Méadel, and Rabeharisoa 2002; Hutter and Throsby 2008; Karpik 2010; Stark 2009; Uzzi and Lancaster 2004). Especially in markets for goods that are valued for their aesthetic qualities, the ascription of value and the distinction between product qualities appears to be a complex social process. In one of the most insightful treatments of the subject, Lucien Karpik (2010) analyzes the valuation of aesthetic goods in a framework he calls the "economics of singularities." How are products or services evaluated, classified, and —ultimately—priced whose qualities are unique, incommensurable, and uncertain?

The problem of assessing the quality of goods goes far beyond the description of quality uncertainty analyzed famously by George Akerlof (1970) in his model for "the Market for Lemons." Akerlof saw quality uncertainty as an information problem about the objective characteristics of a product. The potential buyer of the product is uninformed about some of its qualities. Asymmetric distribution of information on quality can lead, as Akerlof demonstrated, to market failure. In many markets, however, quality uncertainty is not a problem with information about the product itself but about its social context and usage. When the buyer of a painting of a

IMax Planck Institute for the Study of Societies, Cologne, Germany

2University of Zurich, Zurich, Switzerland

Corresponding Author:

Jörg Rössel, Institute for Sociology, University of Zurich, Andreasstrasse I5, 8050 Zurich, Switzerland.

Email: roessel@soziologie.uzh.ch 
contemporary artist looks at the painting he or she wishes to acquire, he or she can see all the properties of the painting: its size, the materials used, the shape, and possible damages. And the gallery owner will willingly provide all the information he or she has on the artist and the painting. But why does the painting cost, let's say, 3,000 Euros? And why does the painting by another artist, offered in the gallery next door, which looks pretty similar and has roughly the same size cost only 800 Euros? Whatever the answer to this question is, it is clear that price differences and underlying perceived quality differences are not caused exclusively by the objective features of the product and asymmetrically distributed information of these objective features.

The wine market is an extraordinary example for a market for singularities. Although chemically largely the same, a bottle of wine can cost 1.99 Euros or 300 Euros. These price differences are justified by alleged quality differences between the wines. However, on closer inspection, it turns out that the price differences are not simply determined by different production costs and the sensual experience wine connoisseurs are reporting when tasting the wine in a blind tasting. According to statements of insiders in the wine field, even very expensive wines do not have production costs above 10 Euros per bottle. ${ }^{1}$ Many experimental studies have shown that even experts are at loss when it comes to describe and to compare different wines simply from the taste (Gawel 1997; Lawless 1984; Lehrer 1975; Solomon 1997; Weil 2007). Most consumers and even experts are not able to differentiate between wines based on objective sensory characteristics and cannot rank wines according to their price (for an overview, see Rössel and Beckert 2013). What constitutes the complexity in quality assessment in the wine market is not only that there are several thousand producers each producing several different wines. In addition, the taste of the products changes with each new vintage. This naturally caused newness creates recurrently additional uncertainty that is even increased by the not completely predictable results of aging (Howland 2013). How can we explain price differences for different wines if these cannot simply be attributed to the sensual preferences of the consumer? Through what processes are the products "qualified"?

These questions are relevant in almost all consumer markets. The perceived quality of wine, perfume, art, music, food, computer technology, and even cars is only partially derived from their material characteristics. Their value stems furthermore from symbolic qualities ascribed to the products based on the interpretation of the product, such as the virility attributed to cars with strong engines or the intellectuality attributed to listening to contemporary serious music. In affluent consumer societies, in which functional needs are mostly satisfied, the value produced in the economy resembles increasingly the type of valuation we can observe in the art market or in the wine market (Beckert 2011). Studying markets such as the wine market thus helps us to develop the analytical tools to understand much wider aspects of the contemporary economy.

In this paper, we address the question of qualification of goods through the investigation of the German wine market. We want to explain price differences in this market based on the underlying differences in the valuation of quality characteristics of wine. Our premise is that assessed quality differences cannot be explained by the sensual qualities of the wine but are also not random. Instead we explain variations in valuation by social processes in which quality is constructed and contested. To do so, we make use of Bourdieu's field theoretical perspective. Bourdieu's theory of fields analyzes the process of cultural consecration of specific goods in differentiated societal fields and relates these symbolic valuations to the economic and social status of producers and consumers, who struggle for status in the field and thus shape and reshape discursively the value of goods. The valuation of products is thus related to social context and not left unexplained simply as an individual taste. Bourdieu shows how symbolic values (symbolic capital) are formed in differentiated social fields and how these values impact on price formation (Bourdieu 1996). His theory offers a general model of processes of symbolic valuation and price formation that takes into account dissonances of valuation. These differences reflect status differences among producers and consumers and are thus socially constituted. Moments of valuation, as we show based on 
Bourdieu's theory, are always socially preconfigured. We take Bourdieu's theory to explain the formation of symbolic value in the wine field and its impact on prices in the wine market on one hand and to explain the preferences and orientation of consumers on the other.

Making use of Bourdieu's theory of fields in the analysis of the wine market adds to a growing literature in economic sociology that analyzes economic structures as fields and take up Bourdieu's theoretical perspective for questions of economic sociology (Beckert 2010; Fligstein and McAdam 2012; Hanappi 2011; Swedberg 2011). This perspective figures prominently not only in the analysis of markets (Fligstein 2001) but also in the investigation of organizations (DiMaggio and Powell 1983). In a field, perspective markets are seen as being composed of a whole set of actors, among them producers and sellers, experts, journalists, industry associations, marketing specialists, regulatory agencies, and consumers (Bourdieu 1996; Dubuisson-Quellier 2013; Eymard-Duvernay 2002; Karpik 2010). These actors are positioned in relation to each other. They all participate in the construction of the qualities of the products sold in the market.

In the first section of the article, we will first outline Bourdieu's theory of fields as it is to be used for the analysis of product qualification. In the second part of the article, we test the implications of Bourdieu's theory with data on the German wine field. We collected price information on wines from more than 100 wineries from two German wine regions: the Rheingau and Rheinhessen. Through a content analysis of the Web sites of these wineries, we gathered additional data on their symbolic positions in the wine field. This is an important though only partial measurement of the symbolic positioning of the vineyards and the discursive process in the wine field. Based on these data, we can statistically analyze the relation between symbolic capital and prices for the sample of wineries and wines. In a second step, we add data from a comprehensive survey on wine consumption in random population samples from four German cities (Hamburg, Cologne, Wiesbaden, and Mainz; Pape 2012). This allows us to take up the consumers' side of the market and analyze the relationship between symbolic positions of wines and wineries and the valuation of wines of consumers in connection with their position in the class hierarchy. By studying a societal field both from the perspective of producers and the perspective of consumers, the paper provides insights into the interface between supply and demand on a market characterized by the importance of symbolic product qualities.

\section{Symbolic Capital and Price Formation in the Wine Field}

Pierre Bourdieu developed a comprehensive theory of social fields. It is an attempt to explain the behavior of actors in market-like situations not from an economic point of view, but from an encompassing sociological perspective. A field is a network of objective relations between positions endowed with different types and levels of capital (Bourdieu 1996; Bourdieu and Wacquant 1992). In contrast to interactionist approaches (Becker 1982; White 1981), Bourdieu focuses on objective positions and objective relations between these positions, which shape the interactions between position holders. Positions in a field are defined by a certain endowment with different forms of capital. Thus, they exist independently from their incumbents (Bourdieu 1993). Two main groups of capital are relevant for the definition of objective positions within fields: There are universal forms of capital, like economic and cultural capital, which are important in all areas of the social space. And there are specific forms of capital, which are valuable only in the context of a certain field (Bourdieu 1993; Bourdieu and Wacquant 1992). In the field of wine, such specific forms of capital may be the technology of the production process (industrial vs. crafts production), the size and the location of vineyard plots, and of course the symbolic recognition (i.e., symbolic capital) gained in the field of wine (Diaz-Bone 2005).

The objective relations between positions are relations of power. The objective network of relations between such positions explains the strategies that actors use and thus the interactions between them (Bourdieu 1985). Strategies aim at safeguarding a position in the field or to gain a 
better position in the field. Actors invest their different forms of capital to obtain different forms of profit. In Bourdieu's theory, this is not considered as a conscious or rational process, but based on a dispositional sense of placement, inscribed into the persons' habitus. To do so, they need to develop specific strategies that are based on their capital endowment. To carve out a distinctive and profitable niche for themselves, producers must develop distinct strategies (Bourdieu 1996). However, in contrast to economic approaches, Bourdieu's theory assumes that in many fields actors do not directly aim for economic gains. Instead they aim at symbolic profits, which may be transformed into economic profits (Bourdieu 1996; Bourdieu and Wacquant 1992). Each field is based on a set of common assumptions, which are taken for granted by the actors (nomos, doxa) and on the strong motivations of the actors to invest into the field and a belief in the symbolic profits to be gained in the field (illusio; Bourdieu 1996; Bourdieu and Wacquant 1992). Therefore, a winemaker may mention as his prime motivation the love of wine and the urge to create a unique and fascinating wine, but not the intention to first of all make money from producing wine (Schenk and Rössel 2012; Scott-Morton and Podolny 2002). However, in the end Bourdieu perceives the struggle for power and status as the ultimate motivation behind the illusio, effectively deemphasizing the field-specific motivations too strongly (Friedland 2009). Based on the field-specific motivations and the different positions of producers and consumers, the product becomes differently evaluated not only by consumers and producers but also by the different groups of producers and consumers based on, for example, ethnic, gender, or class differences. The specific valuation is explained by the position of the respective actor in the field and is thus socially contextualized.

The degree to which symbolic profits play a role depends on the relation between the respective field and the field of power. The field of power may be described as a kind of meta-field, where the dominant social groups struggle over the importance and exchange rates of different kinds of capital. The greater the distance between a certain field and the field of power, the higher the autonomy of this field and the more important the internal, field-specific criteria for evaluating its products. In strictly economic fields, actors may directly strive for economic profits. In fields with a larger autonomy and an emphasis on cultural production, producers may first invest in symbolic capital, which is then quickly transformed into economic profits. In highly autonomous fields, like visual arts or contemporary music, there is a substantial time lag between the acquisition of symbolic capital and its eventual transformation into economic capital (see, for example, Galenson 2001, as well as Accominotti 2009; Ginsburgh and Weyers 2006).

The autonomy of fields and thus the relationship between economic criteria of evaluation and symbolic criteria varies not only between different fields, but also between the same field in different countries and within the same field over time. Marc Verboord (2011) has shown for the literary field that in the last 40 years economic criteria of evaluation have won in prominence. The precursor of this development is the literary field in the United States. In contrast, for the field of wine, there is evidence of a growing importance of symbolic criteria of evaluation. One indicator for this is the increase in wine reporting. The number of specialized wine magazines has grown and important popular journals have extended the number of articles on wine. Furthermore, in the news coverage of wine, there is an increasing emphasis on questions of taste and aesthetics and a declining relevance of economic issues (Diaz-Bone 2005; Rössel, Schenk, and Eppler 2015). These developments suggest an increase in the public discourse about the aesthetic qualities of wine that can be taken as an indicator for an evolution of the wine field that strengthens the relevance of symbolic quality criteria for the evaluation of wines.

Not only fields differ in their degree of autonomy, but also the subfields existing within fields. Bourdieu has shown that fields usually have a chiastic structure. In one subfield, actors are more oriented toward external criteria, for example, sales and economic profits, whereas in the other subfield, actors have a stronger orientation toward internal criteria of evaluation (Bourdieu 1996). The first type of subfield constitutes the heteronomous pole of the field, as the actors here are less 
driven by field-internal criteria, whereas the second subfield is more autonomous from external criteria (Bourdieu and Wacquant 1992:103). On the heteronomous pole, producers are oriented toward the pre-existing demand, therefore tending toward standardized mass production. At the autonomous pole, producers are usually oriented toward a narrow group of field-internal experts and institutions with a high endowment of symbolic capital, thus producing for a restricted market (Bourdieu 1996).

This chiastic structure of fields of production is also visible in the fields of distribution and in public discourses about products. Certain types of market intermediaries such as critics, journalists, and sellers cater more to the restricted subfield and others more to the market oriented subfield. Thus there is a homology between the fields of production and the field of distribution and discourse. On the autonomous pole of a field, we usually expect to find intermediaries driven by field-internal criteria of evaluation. Among them one may count critics, intellectuals, avant-garde art galleries, journalists from quality newspapers. In contrast, on the heteronomous pole, one finds actors oriented toward economic criteria, like marketing specialists, big art stores or book stores, journalists from tabloids, and bestseller lists. This bifurcation of fields is also visible in the wine field: On the autonomous pole, we find actors like wine critics, quality journals, specialist stores, direct purchasing from the winemaker. On the heteronomous pole, we find an absence of independent critics and quality journals, a presence of contract grape growing, blending of wines from different areas and even countries, and supermarket chains as major forms of distribution and selling (Diaz-Bone 2005; Schenk and Rössel 2012).

This model assumes that the production of a certain good or service is not just an act of material production, but also a symbolic act (Bourdieu 1996). Therefore, the value of works of art is not solely created by the artists, but both, the value of works and artists, are created by the multiplicity of actors in the field like critics, curators, journalists and gallery owners, which transubstantiate persons into artists and objects into art works (Bourdieu 1996). Thus, the discourse about art or other cultural products is part of the production process itself:

It [the science of cultural products] must therefore take into account not only the direct producers of the work in its materiality (artist, writer, etc.), but also the ensemble of agents and institutions which participate in the production of the value of the work via the production of the belief in the value of art in general and in the distinctive value of this or that work of art. We may include critics, art historians, publishers, gallery directors, dealers, museum curators, patrons, collectors . . . (Bourdieu 1996:229)

As outlined above, this process is of greater importance in more autonomous fields, like visual arts or contemporary music, but the process is even visible in many economic subfields. Bourdieu has shown, for instance, for the field of real estate, that producers may invest in symbolic profits to enhance their economic profits (Bourdieu 1985, 1996, 2005). Similar to the way artists in the restricted subfield distance themselves from public demands and external criteria, producers in less autonomous fields gain symbolic profit by positioning themselves as luxurious, craft oriented, authentic, and local (Bourdieu 1993, 2005). Some producers may even relate themselves to artists by emphasizing the noble materials used or the uniqueness of their products (Bourdieu 2005) to distance themselves from standardized, mass-produced goods and a short-term sales orientation. The fashion industry and the car industry are examples for this.

We find similar strategies of symbolic positioning in the wine field. In the subfield of restricted production, the autonomous pole, the winemakers distance themselves from industrial methods of production, and emphasize the importance of craft production and of the natural conditions of their vineyard. Often they distance themselves from the general public, by emphasizing that it is difficult to "comprehend" their wine and that it takes time to understand them. Thereby, they distance themselves from a purely economic focus on sales (Schenk and Rössel 2012). This 
differentiation also takes place on the consumer side of markets. Some winemakers even suggest a certain similarity between wine making and art. In general there is the underlying idea, that a certain wine has an authentic quality to it (Beverland 2005; Gade 2004; Schenk and Rössel 2012). Josée Johnston and Shyon Baumann (2007) have demonstrated that high-status consumers in contemporary food markets, of which the wine market is one segment, tend to distinguish themselves from lower class consumers by looking for authentic and exotic food. Food is not a simple material product, but a product with symbolic qualities (Pratt 2008).

Bourdieu situates producers in cultural production. He explains their different strategies by the governing assumptions and motivations in the respective field and the respective position of the producer in the field. In contrast to economic perspectives, he further assumes that the relevance of a given sort of capital is not simply given, but is the object of struggles in the field. To put it differently, what is at stake in the wine field is the definition of the quality of wine itself. Therefore, field-specific assessments of quality may change because of changes in the power structures of the field or due to changes in the relation to the field of power (Bourdieu 1996; Bourdieu and Wacquant 1992). In contrast to theories of functional differentiation (Luhmann 1997), Bourdieu's theory of fields is capable to explain changes in social fields, as it does not assume that its autonomy is a given.

\section{Linking Producers with Consumers}

Bourdieu's field theory contains not only a sociological analysis of producers. His model is more comprehensive by linking producers to consumers. The crucial assumption is again that of a homology. Of course producers and consumers differ in the first being interested in profits and the second being interested in a product that fits their lifestyle and signals distinction. But at the same time, there is a homology between the symbolic hierarchy of producers in a field and the social status hierarchy of consumers (Bourdieu 1996). This stands close to the discussion of status markets in economic sociology (Aspers 2009). Producers in the more autonomous subfields of a certain field usually cater to an audience with a more ample capital endowment. It holds especially for cultural products that consumers differ in their ability to understand and consume certain products.

Usually all consumers are able to understand and consume goods and services that are standardized and mass produced (Bourdieu 1996). However, products and services from the subfield of restricted production usually reflect the history of the field and thus are rather full of preconditions for understanding. Only consumers who are familiar with the history and preconditions of the subfield are able to understand and enjoy its products. The ability to understand and enjoy a product is based on the consumer's habitus. Following Bourdieu, habitus is the system of perceiving and classifying the world as well as the systematic dispositions for behavior (Bourdieu 1984). In the case of cultural products, habitus also contains the consumer's taste, which is crucial for the choices being made between products from the different subfields (Bourdieu 1984, 2005). The habitus itself is shaped by the social conditions of a person, especially his or her class location, which is not only based on the persons' own capital endowment, but also on family background. This is why Bourdieu asserts that consumers from different class backgrounds differ in their tastes for music, art, food, wine, and so forth (Bourdieu 1984, 2005). More precisely, consumers not only diverge in terms of what they consume, but also in the way they consume it and in the quality of the experience that is linked with the act of consumption. This is in line with the idea that processes of distinction are often not based on what people consume, but on the way and manner they consume (Holt 1997; Johnston and Baumann 2007; Rössel 2011).

The social differentiation of the assessment of wine quality shows itself today, for instance, in the different preferences for sweet and dry wines. It is mostly the inexperienced consumer, often young and of low social status, who will favor sweet wines, whereas the experienced wine 
consumer, especially if he or she has higher social status, will favor dry wines. ${ }^{2}$ A recent study of the German wine market shows that wine consumption in all its different facets (consumption frequency, expenditure, taste preferences) is strongly shaped along a vertical social axis differentiated by income and education (Pape 2012).

The habitus generates a coherent and systematic way of evaluating the symbolic qualities of wine that adds up to an identifiable lifestyle. As the habitus is linked to the social position of the consumer, other actors can infer the lifestyle of a person and his or her position in the social space by observing his or her consumption behavior. In this sense, the consumption of wine is a signifier for the lifestyle and the class position of an individual (Bourdieu 1984). As cultural products are produced according to a competitive logic, resulting in distinctive positions and niches for different products and artists, they are well suited for the expression of social distinctions; thus, there is a dynamic interplay between the producers' struggles for positions within the field and the consumers' struggle for distinction.

By also locating consumer taste in class position and individual biographies, Bourdieu analyzes consumption practices as the result of the concurrence of two processes: the genesis of consumers with certain tastes, based on certain presuppositions and classifications, and of producers and products, based on the same presuppositions and classifications (Bourdieu 1996). In this way, Bourdieu locates both production and consumption in social context.

\section{Data and Methods}

To analyze the price of wine in its relation to field differentiation, we assembled information on a set of wineries from the two German wine regions of Rheingau and Rheinhessen. The set consists of the wineries from these two regions that were included in the Gault Millau wine guide for 2007 and of the wineries that were included in the wine guide published by the Deutsche Landwirtschaftsgesellschaft in 2007. In addition, we included the wines from these two regions that were listed by nine different supermarket chains. The wineries were chosen so as to include most types of wineries in the field, which ranged from vast wine cellars to small family wineries (see Schenk and Rössel 2012).

Our sample includes 1,071 wines from 110 wineries located in the appellations of Rheingau and Rheinhessen. Methodologically, this implies that the analysis of individual wines had a multilevel data structure that had to be taken into account (Snijders and Bosker 1999). We used a multilevel model with random intercepts for the data analysis. We proceeded in an explorative manner by gradually eliminating insignificant variables for the symbolic positions.

Our hypothesis is, based on Bourdieu's theory, that wines that stem from producers closer to the autonomous pole of the field have higher prices. Consumers with higher cultural and economic capital value wines with the corresponding symbolic quality attributes higher and are thus willing to spend more money for such a wine. To operationalize the symbolic positions of the different wineries, we conducted a content analysis of the wine producers' Web sites. Of course, this captures only one aspect of the discursive process in the wine field and even with regard to the vineyards' symbolic position, their Web sites are only a proxy for grasping their full symbolic practices in the field. We used the following eight variables to capture the symbolic positions. ${ }^{3}$

On the autonomous side of the field we first included a variable that reflects the artistic orientation of the winemaker ("art"). Winemakers distinguish themselves by relating their work to the world of art, thereby framing the good as a cultural product and distancing it from the profane world of economic production (Johnston and Baumann 2007), like in the following quote: "Good wine requires philosophy and artistry, not technology." This entails that the production of wine is claimed to be pursued for its own sake - a stance that is analogous to the statement of "l'art pour l'art" within the field of art (Bourdieu 1996:216). Furthermore, this variable is a strong indicator for the aestheticization that takes place in certain parts of the field of wine (Rössel et al. 2015; Schulze 1992). 
Table I. Symbolic Positions within the Wine Field.

\begin{tabular}{ll}
\hline Variable name & Description \\
\hline Art & $\begin{array}{c}\text { By relating the wine production to the world of art, the wine is } \\
\text { framed as a cultural product high in aesthetic value } \\
\text { A field-specific notion of quality that stresses the significance of } \\
\text { the specific vineyard and the artisan work of the winemaker } \\
\text { Descriptions of the specified, small wine-growing area, including } \\
\text { denomination, topography, or specific soils } \\
\text { The wine production is related to the region's history, including } \\
\text { traditional grapes or production methods } \\
\text { Regional tradition }\end{array} \quad \begin{array}{c}\text { Economic considerations such as market trends, prices, costs, or } \\
\text { profit are mentioned } \\
\text { Representation of the winemaker as a large-scale producer } \\
\text { supplying a standardized good for the mass market } \\
\text { Mass production }\end{array}$ \\
Usage of modern production methods, such as artificial heist, full \\
automatic harvesters, or steel tanks is mentioned
\end{tabular}

Second, we included a variable that represents the notion of "terroir." Terroir is a complex concept that developed historically within the French field of wine, which has a global importance for the wine discourse. Therefore, we can interpret it as an archetype of a field-specific quality criterion. Basically the notion of terroir posits that the quality of the wine stems from the complex interaction between the natural properties of the vineyard and the artisan work of the winemaker that is informed by the specific tradition of the region. Therefore, the concept of terroir stresses the distinctiveness and the authenticity of the individual wine (Karpik 2010). Only those wineries that use the concept terroir literally were coded in this variable.

The last two measures for the symbolic positions at the autonomous pole are "delimited winegrowing area" and "regional tradition" (see Table 1). The former was coded when a classified vineyard was mentioned ${ }^{4}$ or a detailed description of the vineyard, its location, its microclimate, or its soil was given and the latter when the production of wine was linked to the region's history including traditional production methods or grapes, which are traditional and typical for a certain region. A characteristic example would be to link the winery to the existence of viticulture in its area since the Romans. As vineyards and regions enjoy different reputations, these variables are primarily related to the producers' symbolic capital (Benjamin and Podolny 1999; Gade 2004).

Turning to the symbolic positions that are associated with the heteronomous pole of the field, we included a variable that measures the "economic orientation" of the producer and a variable capturing an orientation toward "mass production." The former reflects the consideration of economic necessities dictated by the market, like emphasizing the "astonishing quality of wine, therefore giving a high value for money." The latter symbolically represents a strategy of large-scale production (Diaz-Bone 2005; Schenk and Rössel 2012), indicated by direct references to the scale of production on the homepages of the wineries. Furthermore, we added a variable that measures the mentioning of "modern production methods," such as the usage of artificial yeast during the fermentation process. Last, we included a variable that reflects the producer's "orientation towards the consumers' taste" like in the following quote: "It is not only important to respond sensitively to consumers' reactions but also to compare our products permanently with those of our competitors." The positions at the heteronomous pole reflect an orientation toward "worldly" success (namely, the accumulation of economic capital) and its representation as a virtue rather than a vice. The alignment of production with consumer's demand is characteristic for the heteronomy of a field and encounters negative sanctions by producers with an autonomous orientation (Bourdieu 1996; Johnston and Baumann 2007). 
Apart from these variables that indicate symbolic positions, we included a series of variables in our models that could be assumed to influence the perception of the quality of a wine and therefore its price (Frick 2004, 2010; Landon and Smith 1997; Schamel 2003): First, we included bottle size. In the German wine market, one-liter bottles are used next to the 0.75 -liter bottles. The wine bottled in one-liter bottles is usually perceived as being of lower quality. Second, we included a variable for different grape varieties. Riesling and Pinot are the most important and most prestigious grape varieties in the two regions studied, so we included two dummy variables indicating whether a certain wine contained mainly one of those two grape varieties. The reference category included all other grape varieties. Third, we differentiated between red wines and white and rosé wines. ${ }^{5}$ Fourth, we took in one variable indicating the wines' age in 2007, assuming that older wines would be more expensive (the latter are categorized in one category). Fifth, German wines are produced in different categories of sweetness. We included a dummy variable for sweet wine and one for semidry wines; the reference category contained dry wines. Finally, we added a set of dummy variables for the different categories of quality wine according to the wine law from 1971 (Kabinett, Spätlese, Auslese, Beerenauslese, Trockenbeerenauslese, Eiswein); the reference category was a quality wine without a descriptor (for the recent discussion about this wine law, see Weik 2015).

In addition to this information on the producer side, we collected data on the consumer side of the field. We analyzed the consumption of wine by conducting a standardized mail survey in the population of four German cities: Mainz, Wiesbaden, Hamburg, and Cologne (Pape 2012). The population consists of all residents with an age of 18 years or older and German citizenship. Taking neutral sampling failures into account, we attained an adjusted response rate of 27 percent. The survey asked in a very comprehensive manner about preferences, drinking patterns, and practices related to wine. For the data analysis, we used a series of ordinary least squares regressions. To enhance comparability, we kept the number of cases constant across all models, which yielded 617 cases for the analysis.

The dependent variables encompass several measures that reflect distinct aspects of wine consumption, which conveys a sense of the persons' habitus at a certain point of its development and unfolding. First, we looked at the price that respondents are willing to pay for a bottle of wine. We computed an additive index based on questions concerning the average amount and the maximum amount people spend on wine (Cronbach's $\alpha=.875$ ). Second, we computed an additive index that represents the respondents' taste for dry wines based on three indicators, one for white, one for red, and one for rosé wine (Cronbach's $\alpha=.865$ ). Higher values indicate a preference for dry wines, which are especially favored on the autonomous pole of the field. Our third measure, "specialized press," reflects the extent to which consumers gather information about quality assessments by field-specific intermediaries, which are usually oriented toward the autonomous pole of the field. Respondents were able to indicate how often they turn to wine critics or how often they collect information in wine guides or books devoted to wine (Cronbach's $\alpha=.709$ ). The fourth dependent variable is concerned with the usage of a field-specific distribution channel, namely, the frequency with which consumers purchase the product from the winemaker directly. This signals the circumvention of more commercial sales venues like chain supermarkets or discount stores. The fifth dependent measure is an additive index that summarizes the importance of different quality criteria which are specific mainly for the autonomous pole of the field of wine (Cronbach's $\alpha=0.878$ ). These include the region, the vineyard, the producer, the production method and the year of production. ${ }^{6}$ The last measure draws on Pierre Bourdieu's (1984) idea that a person's taste functions as a signifier for his or her lifestyle and social position: Respondents indicated whether they think that wine consumption allows an inference about the person and thus has a distinctive value. ${ }^{7}$

Considering the independent variables, we included the respondent's age measured in years, the respondent's gender with males coded as 1 and females coded as 0 , the household 
equivalence income (e.g., economic capital), and the respondent's education measured in years of schooling (e.g., cultural capital). Income and education are measures of economic and cultural capital and therefore indicate the class position of our respondents. To take the importance of early formation of the habitus within the family into account (Bourdieu 1984), we included a variable that reflects a wine-specific socialization of the respondent. Participants were asked to rate their agreement with the statement, "The consumption of wine was common in my parental home." Last, we included three dummy variables for the cities Hamburg, Mainz, and Wiesbaden with Cologne as the reference category.

\section{Empirical Results}

\section{Production Data}

Model 1, the so-called empty model that includes no explanatory variables, shows quite clearly that we had to conduct a multilevel analysis, as nearly half of the variance of the dependent variable, price, is accounted for by the clustering of individual wines in wineries (see Table 2). In the next step (Model 2), we included the whole set of control variables that should be taken into account in the explanation of price formation in the wine market. The results confirm the results of previous studies of the wine market (Cardebat and Figuet 2004; Combris, Lecocq, and Visser 2000; Landon and Smith 1997; Rössel and Beckert 2013; Schamel 2003; Zhao 2008): the larger the bottle, the lower the price per liter; wines made of high-status grape varieties (Riesling, Pinot) are usually more expensive; dry wine is more expensive than sweet and semidry wine; and red wine is more expensive than white and rosé wines. Finally, older wine is usually more expensive than wine of a younger age. Furthermore, prices follow the logic of the German wine classification. Interestingly, in comparison with the reference category (quality wine without descriptor) the category Kabinett attains lower price levels and even wines of the renowned category Spätlese have only a slightly higher price. This effect is explained by the fact that a number of very prestigious wineries in Germany boycott the official classification system and use only the lowest category for quality wines for their wines, even if they could classify them in a higher category (Rössel and Beckert 2013; Weik 2015).

All these effects of the control variables are stable in all models. Interestingly, these variables are better suited to explain the price differences of wines from the same winery $\left(R^{2}\right.$ of .52) than to explain the price differences between wineries ( $R^{2}$ of .22). In Model 3, we only entered the symbolic positions of the wineries. A look at the $R^{2}$ shows that these variables are not at all able to explain the price differences between wines from the same winery; they can only be explained by wine-specific variables like style (sweet, dry) or color. However, the symbolic strategies have a strong influence on the price differences between wineries $\left(R^{2}\right.$ of .48$)$. This clearly shows that the symbolic positions of winemakers in the field of wine have a strong impact on their ability to gain economic profits. This empirical result confirms the main claim of Bourdieu's field theory.

However, the eight variables we have included do not make up a serious theory test, as we worked in an explorative way to find out the most important symbolic positions. Nevertheless, these eight symbolic positions are clearly in agreement with Bourdieu's description of the two poles of chiastic cultural production fields. An orientation toward predefined consumer demand, toward the economic field, based on mass production and modern industrial technology clearly lowers the mean price per bottle of wine. However, a comparison of wine making with art, a focus on restricted and authentic production (terroir, delimited wine-growing area, regional tradition) increases the mean price of a bottle from a specific winery. As one can see from Model 4, nearly all effects are stable controlling for all the variables from Model 2. Only "terroir" loses its statistical significance. This is a rather new term in the German wine discourse that is so far used by only some of the wineries (Schenk and Rössel 2012).

The homology between the symbolic positions taken by the wineries and their impact on price levels on one hand and Bourdieu's description of symbolic positions on the two poles of fields of 
Table 2. Multilevel model of wine prices.

\begin{tabular}{|c|c|c|c|c|}
\hline $\begin{array}{l}\text { Independent } \\
\text { Variable }\end{array}$ & Model I & Model 2 & Model 3 & Model 4 \\
\hline Art & & & $4.11 \mathrm{I} * *(2.55)$ & $2.901 * *(2.08)$ \\
\hline Terroir & & & $6.886 *(1.92)$ & $4.514(1.42)$ \\
\hline $\begin{array}{l}\text { Delimited wine- } \\
\text { growing area }\end{array}$ & & & $2.317 * * *(3.48)$ & $2.104 * * *(3.58)$ \\
\hline Regional tradition & & & $5.406 * *(2.17)$ & 4.566 ** (2.07) \\
\hline $\begin{array}{l}\text { Economic } \\
\text { orientation }\end{array}$ & & & $-11.202 * * *(-3.07)$ & $-10.267^{* * *}(-3.19)$ \\
\hline Mass production & & & $-18.558 * * *(-3.92)$ & $-13.968 * * *(-3.31)$ \\
\hline $\begin{array}{l}\text { Modern production } \\
\text { methods }\end{array}$ & & & $-4.706 *(-1.91)$ & $-4.765 * *(-2.21)$ \\
\hline Consumer taste & & & $-3.343 *(-1.85)$ & $-3.604 * *(-2.26)$ \\
\hline Bottle size & & $-2.278^{* * * *}(-16.04)$ & & $-2.27 * * *(-16.08)$ \\
\hline Pinot & & 0.131 1*** (3.47) & & $0.123 * * * *(3.29)$ \\
\hline Riesling & & $0.184 * * *(6.22)$ & & $0.181 * * *(6.18)$ \\
\hline Red wine ${ }^{a}$ & & $0.170 * * *(4.98)$ & & $0.179 * * *(5.31)$ \\
\hline Age & & $0.125^{* * *}(8.04)$ & & $0.120 * * *(7.82)$ \\
\hline Sweet & & $-0.213 * * *(-4.85)$ & & $-0.205^{* * *}(-4.69)$ \\
\hline Semidry & & $-0.170 * * *(-4.67)$ & & $-0.159 * * *(-4.39)$ \\
\hline Kabinett & & $-0.234 * * *(-5.86)$ & & $-0.24 I^{* * *}(-6.07)$ \\
\hline Spätlese & & $0.080 * *(2.40)$ & & $0.072 * *(2.20)$ \\
\hline Auslese & & $0.308 * * *(4.83)$ & & $0.314 * * *(4.95)$ \\
\hline Beerenauslese, etc. & & $0.614^{* * *}(6.34)$ & & $0.633 * * *(6.65)$ \\
\hline Intercept & $2.268 * * * *(50.68)$ & $3.597 * * *(28.74)$ & $2.202 * * *(34.87)$ & $3.566 * * * *(27.06)$ \\
\hline Variance $u$ & 0.432 & 0.382 & 0.310 & 0.287 \\
\hline Variance e & 0.472 & 0.327 & 0.472 & 0.327 \\
\hline$\rho$ & .455 & .577 & .302 & .436 \\
\hline$R^{2}$ within & .000 & .519 & .002 & .521 \\
\hline$R^{2}$ between & 0 & .216 & .484 & .558 \\
\hline$R^{2}$ overall & 0 & .381 & .221 & .538 \\
\hline$N$ level I & $|, 07|$ & $|, 07|$ & $|, 07|$ & $|, 07|$ \\
\hline$N$ level 2 & 110 & 110 & 110 & 110 \\
\hline
\end{tabular}

Note. Presented are unstandardized regression coefficients and $z$ values in parentheses.

aReference category: white and rosé.

*Significant at 10\%. **Significant at 5\%.***Significant at $1 \%$. Two-tailed.

cultural production on the other is rather striking. Our results substantiate the idea that one way of gaining economic revenues in economic markets is via an indirect strategy of first gaining and accumulating symbolic capital in cultural production fields and subsequently to transform this symbolic capital into economic returns. There is of course a second strategy of catering to the predefined consumer demands by mass producing standardized and rather inexpensive wines. This strategy leads only to economic profits and not to a leading symbolic position in the wine field.

\section{Consumption Data}

One of the main ideas of Bourdieu's field theory is the assumption of a homology between the structure of production and consumption. If this holds true, one should expect high-status consumers with above average income and education to focus on criteria and actors who belong to the autonomous pole of the field, to pay higher prices for wine and to see wine consumption as 
an activity allowing for social distinction. In the interpretation of our empirical analysis, we focus mainly on the results of class-related variables like income, education, and wine socialization, whereas we tend to neglect control variables like age, gender, and city of residence. Our main goal is to show the relationship between wine consumption and class and not a comprehensive explanation of wine consumption.

Looking first at the willingness to pay a higher price for wine, we find that all three classrelated variables have a significant positive impact on the dependent variable (see Table 3). Higher class consumers are more willing to pay a higher price for wine. This of course is not a surprising result. More interesting are the other results. Our next dependent variable measures the preference for dry wines, which is a typical taste at the autonomous pole of the wine field. Here we find the same result as for willingness to pay. All three class-related variables have a positive influence on the preference for dry wines among consumers. This shows that class position does not only shape the resources for wine consumption, but also the taste, like Bourdieu's habitus theory assumes.

The next dependent variable focuses on the use of field-specific sources of information and evaluation of wine. Here, we find a somewhat different result, as only income and wine socialization have a positive effect on the dependent variable, whereas education turns out to be not significant. We have a similar result for the dependent variable that measures the frequency of buying directly from the winemaker, which is a practice strongly related to the autonomous pole of the field, as the distribution and sale does not turn to commercial outlets like supermarket or discounters. However, this practice is of course also strongly shaped by place of residence. Respondents from Mainz and Wiesbaden, which are both located close to wine regions, buy much more frequently directly from the winemaker than interviewees from Hamburg or Cologne.

The following dependent variable includes measures of the symbolic positions that are typical for the autonomous pole of the field, like a preference for artisanal production, small vineyards, and the personality of the winemaker. Here we find again that income and wine socialization have a significant positive effect, whereas education is not significantly related to the dependent variable. Finally, we look at wine as a means of distinction (wine consumption as signifier), which implies the valuation of persons from different social classes based on their aesthetic taste. Here, all three class-related variables again have a positive impact on the dependent variable, which means that persons with high income, high education and a stronger wine socialization tend to think that the choice of a wine allows an inference about the social position of the choosing person.

In summary, the results of the six regressions overwhelmingly support the main idea of Bourdieu's homology thesis. Middle- and upper class persons with a higher income, a higher level of education, and a pronounced wine socialization tend to be oriented toward wine from the autonomous pole of the wine field, insofar as they are more willing to pay, have a preference for dry wine, gather information and evaluations from the internal experts of the wine field based on field-internal quality criteria, and furthermore tend to buy wine directly from the winemaker. This underlines the idea that class distinction is not only based on what persons consume, but furthermore, how they consume certain goods. Finally, they perceive wine to be a good that allows making inferences about the person who has chosen a wine and thus is a marker of social distinction.

\section{Summary and Discussion}

The assessment of wine quality is not simply a question of information about objective characteristics. Instead, the quality of wine is determined in a social process that takes place in a field of cultural production (Bourdieu 1996). Actors with a high endowment of cultural capital are assessing wine quality differently compared with consumers with low cultural capital. Consumers are willing to pay higher prices for wine if the symbolic position of the wine allows for their 


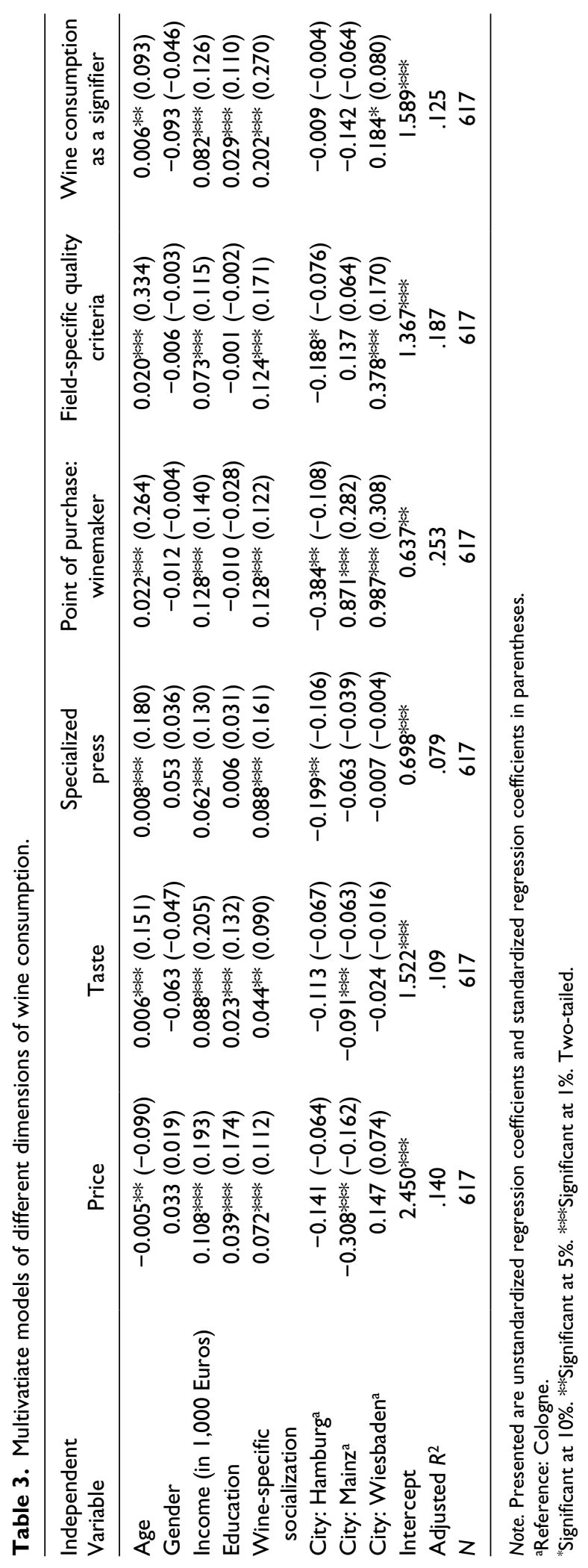


social distinction. Therefore, one major strategy for wine producers is to first gain symbolic capital in the field of wine, which can afterward be transformed into economic profit through higher prices for their produce. Thus, producers' and consumers' strategies are intertwined and thus reproduce the hierarchic structure of the wine field.

In our empirical study, we analyzed data for 110 wineries and 1,071 wines as well as data on wine consumers in four German cities. The symbolic positions of the wineries were gathered by a content analysis of their homepages. Information on consumers derives from a population survey.

Our empirical analysis of the production side has shown that the symbolic positions of wineries have a strong explanatory impact on the price differences between wineries. This is an astounding result, as we captured only a narrow slice of the vineyards' symbolic positions by analyzing only their Web page. Future research based on richer data could uncover even stronger effects. Winemakers with symbolic positions that are typical for the autonomous pole of cultural production fields obtain significantly higher prices on the wine market compared with other wineries. Producers using these symbolic positions make use of symbolic capital and transform it into higher market prices. The symbolic capital accrues especially to wine producers who conceal their economic aims and produce wines that are "difficult" to drink, because the consumer must first "learn" to appreciate them and therefore must "work" on developing taste. This symbolic capital can be transformed into economic capital on the market (Schenk and Rössel 2012). However, this indirect strategy of first gaining symbolic capital, which is afterward transformed into economic profits is of course only one of two alternative economic strategies for wineries. The other strategy is the heteronomous orientation toward direct economic gains and a strict orientation toward the pre-existing demand on the market.

Regarding the consumer side, we have argued that wine quality is interpreted differently according to a person's habitus. The perception of symbolic capital is shaped by the class positions of consumers (Rössel 2011). In the case of upper and middle-class consumers with high economic and cultural capital, symbolic positions from the autonomous pole of cultural production fields enjoy high legitimacy.

Our analysis has shown that Bourdieu's model of the chiastic structure of fields has considerable power in explaining price differentiation between wineries and differences in the valuation of wine by consumers. Furthermore, our empirical analysis of the consumption side of the market has clearly indicated that middle and upper class consumers with higher income, education, and a strong familiarity with and knowledge about the wine field due to their socialization are not only more oriented toward the autonomous pole of the field in terms of sources of information, quality criteria, taste and distribution channels, but are furthermore also prepared to pay higher prices for a bottle of wine. Finally, they also have a stronger disposition to view wine consumption as a practice allowing for social distinction. This strongly substantiates Bourdieu's idea of a homology between the hierarchic structure of field of cultural production and the class hierarchy of the social space.

Bourdieu's theory of fields allowed us to disentangle the workings of symbolic and economic capital that are crucial for the process of product qualification. This demonstrates that the quality uncertainty in markets for products valued for their symbolic qualities, of which the wine market is one example, is of a different kind than the asymmetric information problem discussed by Akerlof (1970) focusing on information about objective characteristics of products. Price differences stem from differences within the symbolic hierarchy in the field. Furthermore, his idea of a homology between production and consumption is clearly visible in the wine field. Bourdieu's theory of production fields is a comprehensive approach to theorize production, consumption, and price formation in one analytical framework and thus helps understanding the processes of value creation in the economy that stand in the center of much current research in economic sociology. Moments of valuation are always already preconfigured by the endowment of actors with symbolic capital. 


\section{Declaration of Conflicting Interests}

The author(s) declared no potential conflicts of interest with respect to the research, authorship, and/or publication of this article.

\section{Funding}

The author(s) received no financial support for the research, authorship, and/or publication of this article.

\section{Notes}

1. Of course production costs vary to a certain degree (Beverland 2005) and should be able to explain partly the variance in prices, but we start from the assumption that besides production costs, there is a lot of leeway for the impact of the symbolic processes discussed in our paper.

2. Of course this does not apply to dessert wines, which are often very prestigious.

3. Each category was measured by its relative frequency based on the total amount of codes per Web site.

4. The status high organization Verband Deutscher Prädikatsweingüter (VDP, or Association of German Prädikat Wine Estates) gives the classification "first class site" to plots of a very high quality.

5. We did not include a separate category for rosé wine, as previous studies did not show a significant difference between white and rosé wines (Schamel 2003) and furthermore, the number of rosé wines in our sample is rather small.

6. Indeed, this construct corresponds semantically to the notion of terroir in the production side analysis.

7. Respondents were asked to rate their agreement with the following statement: "The wine that a person brings with him enables an inference about the person itself."

\section{References}

Accominotti, Fabien. 2009. "Creativity from Interaction: Artistic Movements and the Creativity Careers of Modern Painters.” Poetics 37:267-94.

Akerlof, Georg A. 1970. "The Market for 'Lemons': Quality Uncertainty and the Market Mechanisms." Quarterly Journal of Economics 84:488-500.

Aspers, Patrik. 2009. "Knowledge and Valuation in Markets." Theory and Society 39:111-31.

Becker, Howard S. 1982. Art Worlds. Berkeley, CA: University of California Press.

Beckert, Jens. 2010. "How Do Fields Change? The Interrelations of Institutions, Networks, and Cognition in the Dynamics of Markets." Organization Studies 31:605-27.

Beckert, Jens. 2011. "The Transcending Power of Goods." In The Worth of Goods: Valuation and Pricing in the Economy, edited by Jens Beckert and Patrik Aspers. Oxford, England: Oxford University Press: 106-28.

Beckert, Jens and Patrik Aspers, eds. 2011. The Worth of Goods: Valuation and Pricing in the Economy. Oxford, England: Oxford University Press.

Beckert, Jens and Christine Musselin, eds. 2013. Constructing Quality: The Classification of Goods in Markets. Oxford, England: Oxford University Press.

Beckert, Jens and Jörg Rössel. 2013. "The Price of Art.” European Societies 15(2):178-95.

Benjamin, Berth A. and Joel M. Podolny. 1999. "Status, Quality and Social Order in the California Wine Industry." Administrative Science Quarterly 44:563-89.

Beverland, Michael. 2005. "Crafting Brand Authenticity: The Case of Luxury Wines." Journal of Management Studies 42:1003-29.

Bourdieu, Pierre. 1984. Distinction: A Social Critique of the Judgement of Taste. London, England: Routledge.

Bourdieu, Pierre. 1985. "The Genesis of the Concept of Habitus and of Field." Sociocriticism 2:11-24.

Bourdieu, Pierre. 1993. Sociology in Question. London, England: Sage Publications.

Bourdieu, Pierre. 1996. The Rules of Art: Genesis and Structure of the Literary Field. Cambridge, MA: Polity Press.

Bourdieu, Pierre. 2005. The Social Structures of the Economy. Malden, MA: Polity Press.

Bourdieu, Pierre and Loïc J. D. Wacquant. 1992. An Invitation to Reflexive Sociology. Chicago, IL: The University of Chicago Press. 
Callon, Michel, Cécile Méadel, and Vololona Rabeharisoa. 2002. “The Economy of Qualities.” Economy and Society 31:194-217.

Cardebat, Jean-Marie and Jean-Marc Figuet. 2004. "What Explains Bordeaux Wine Prices?" Applied Economic Letters 11:293-96.

Combris, Pierre, Sébastien Lecocq, and Michael Visser. 2000. "Estimation of a Hedonic Price Equation for Burgundy Wine." Applied Economics 32:961-67.

Diaz-Bone, Rainer. 2005. "Strukturen der Weinwelt und der Weinerfahrung" [Structures of the World of Wine and the Wine Experience]. Sociologia Internationalis 43:25-57.

DiMaggio, Paul J. and Walter W. Powell. 1983. "The Iron Cage Revisited: Institutional Isomorphism and Collective Rationality in Organizational Fields." American Sociological Review 48:147-60.

Dubuisson-Quellier, Sophie. 2013. "From Qualities to Value: Demand Shaping and Market Control in Mass Consumption Markets." In Constructing Quality: The Classification of Goods in the Economy, edited by Jens Beckert and Christine Musselin. Oxford, England: Oxford University Press: 247-267.

Eymard-Duvernay, François. 2002. "Les Qualifications des Biens." Sociologie du travail 44:267-72.

Fligstein, Neil. 2001. The Architecture of Markets: An Economic Sociology of Twenty-first-century Capitalist Societies. Princeton, NJ: Princeton University Press.

Fligstein, Neil and Doug McAdam. 2012. A Theory of Fields. Oxford, England: Oxford University Press.

Frick, Bernd. 2004. "Does Ownership Matter? Empirical Evidence from the German Wine Industry." Kyklos 57:357-86.

Frick, Bernd. 2010. "The Impact of Individual and Collective Reputation on Wine Prices: Empirical Evidence from the Mosel Valley." Presentation at the 4th Annual Conference of the American Association of Wine Economists at the University of California Davis, June 25-28, Davis, CA.

Friedland, Roger. 2009. "The Endless Fields of Pierre Bourdieu." Organization 16:887-917.

Gade, Daniel W. 2004. "Tradition, Territory, and Terroir in French Viniculture: Cassis, France, and Appellation Controlee." Annals of the Association of American Geographers 94:848-67.

Galenson, David W. 2001. Painting outside the Lines: Patterns of Creativity in Modern Art. Cambridge, MA: Harvard University Press.

Gawel, Richard. 1997. "The Use of Language by Trained and Untrained Experienced Wine Tasters." Journal of Sensory Studies 12:267-84.

Ginsburgh, Victor and Sheila Weyers. 2006. "Creativity and Life Cycles of Artists." Journal of Cultural Economics 30:91-107.

Hanappi, Doris. 2011. "Economic Action, Fields and Uncertainty." Journal of Economic Issues 45:785-803.

Holt, Douglas B. 1997. "Distinction in America? Recovering Bourdieu's theory of tastes from ist critics. Poetics 25:93-120.

Howland, Peter J. 2013. "Distinction by Proxy: The Democratization of Fine Wine.” Journal of Sociology 49:325-40.

Hutter, Michael and David Throsby. 2008. Beyond Price: Value in Culture, Economics, and the Arts. Cambridge, England: Cambridge University Press.

Johnston, Josée and Shyon Baumann. 2007. "Democracy versus Distinction: A Study of Omnivorousness in Gourmet Food Writing." American Journal of Sociology 113:165-204.

Karpik, Lucien. 2010. Valuing the Unique: The Economics of Singularities. Princeton, NJ: Princeton University Press.

Landon, Stuart and Constance E. Smith. 1997. "The Use of Quality and Reputation Indicators by Consumers: The Case of Bordeaux Wine." Journal of Consumer Policy 20:289-323.

Lawless, Harry T. 1984. "Flavor Description of White Wines by Expert and Nonexpert Wine Consumers." Journal of Food Science 49:120-23.

Lehrer, Adrienne. 1975. "Talking about Wine.” Language 51:901-23.

Luhmann, Niklas. 1997. Die Gesellschaft der Gesellschaft [The Society of Society]. Frankfurt, Germany: Suhrkamp.

Pape, Simone. 2012. Weinkonsum. Eine Studie zu sozialstrukturellen Determinanten und Lebensstilen im Feld des Weines [Wine Consumption. A Study of the Socio-Structural Determinants and Lifestyles in the Field of Wine]. Wiesbaden, Germany: Springer VS. 
Pratt, Jeffrey. 2008. "Food Values: The Local and the Authentic." In Hidden Hands in the Market: Ethnographies of Fair Trade, Ethical Consumption, and Corporate Social Responsibility, edited by Geert de Neve, Peter Luetchford, Jeffrey Pratt, and Donald C. Wood. Bingley, England: Emerald: 53-70.

Rössel, Jörg. 2011. "Cultural Capital and the Variety of Modes of Cultural Consumption in the Opera Audience." Sociological Quarterly 52:83-103.

Rössel, Jörg and Jens Beckert. 2013. "Quality Classifications in Competition: Price Formation in the German Wine Market." In Constructing Quality: The Classification of Goods in Markets, edited by Jens Beckert and Christine Musselin. Oxford, England: Oxford University Press: 288-318.

Rössel, Jörg, Patrick Schenk, and Dorothea Eppler. 2015. "Feldspezifische Öffentlichkeiten" [FieldSpecific Public Spheres]. In Empirische Kultursoziologie [Empirical Cultural Sociology], edited by Jörg Rössel and Jochen Roose. Wiesbaden, Germany: Springer VS: 353-378.

Schamel, Günter. 2003. “A Hedonic Pricing Model for German Wine.” Agrarwirtschaft 52:247-54.

Schenk, Patrick and Jörg Rössel. 2012. "Identität und Qualität im Weinfeld" [Identiy and Quality in the Field of Wine]. In Feldanalyse als Forschungsprogramm, Band 2: Gegenstandsbezogene Theoriebildung [Field Analysis as a Research Program, Volume 2: Grounded Development of Theories], edited by Stefan Bernard and Christian Schmidt-Wellenburg. Wiesbaden, Germany: VS Verlag: 83-108.

Schulze, Gerhard. 1992. Die Erlebnisgesellschaft: Kultursoziologie der Gegenwart [The Experience Society. Cultural Sociology of the Present Age]. Frankfurt, Germany: Campus Verlag.

Scott-Morton, Fiona M. and Joel M. Podolny. 2002. "Love or Money? The Effects of Owner Motivation in the California Wine Industry." Journal of Industrial Economics 50:431-56.

Snijders, Tom A. B. and Roel J. Bosker. 1999. Multilevel Analysis: An Introduction to Basic and Advanced Multilevel Modeling. London, England: Sage Publications.

Solomon, Gregg E. A. 1997. "Conceptual Change and Wine Expertise." Journal of the Learning Sciences 6:41-60.

Stark, David. 2009. The Sense of Dissonance: Accounts of Worth in Economic Life. Princeton, NJ: Princeton University Press.

Swedberg, Richard. 2011. "The Economic Sociologies of Pierre Bourdieu." Cultural Sociology 5:67-82.

Uzzi, Brian and Ryon Lancaster. 2004. "Embeddedness and Price Formation in the Corporate Law Market." American Sociological Review 69:319-44.

Verboord, Marc. 2011. "Market Logic and Cultural Consecration in French, German and American Bestseller Lists, 1970-2007." Poetics 39:290-315.

Weik, Elke. 2015. "Switching Labels: The Role of Weberian Ideas in Market Change. A Case Study of the German Wine Market." Culture and Organization. DOI:10.1080/14759551.2014.990453.

Weil, Roman L. 2007. "Debunking Critics' Wine Words: Can Amateurs Distinguish the Smell of Asphalt from the Taste of Cherries?" Journal of Wine Economics 2:136-44.

White, Harrison C. 1981. “Where Do Markets Come From?” American Journal of Sociology 87:517-47.

Zhao, Wei. 2008. "Social Categories, Classification Systems, and Determinants of Wine Price in the California and French Wine Industries." Sociological Perspectives 51:163-99.

\section{Author Biographies}

Jens Beckert is Professor of Sociology and Director of the Max Planck Institute for the Study of Societies in Cologne. He has held visiting positions at Princeton University, Harvard University, Cornell University, the European University Institute, Sciences Po and the Institut d'études avancées de Paris. The main focus of his research is economic sociology with a special emphasis on markets, organization studies, the sociology of inheritance and social theory. He is the author of three monographs on the sociology of markets (PUP 2002), the sociology of inheritance (PUP 2008) and on the role of imaginaries in the development of capitalism (HUP 2016).

Jörg Rössel is Professor of Sociology at the University of Zurich. The main focus of his research is economic sociology and consumption, migration and transnationalism and sociology theory. He has published his research in Annals of the American Academy of Political and Social Sciences, European Sociological Review, European Societies, Journal of Consumer Culture, Poetics, Population, Space and Place, Rationality and Society, Sociological Quarterly.

Patrick Schenk is a doctoral student at the University of Zurich. The main focus of his research is economic sociology and consumption, especially the sociology of markets and ethical consumption. 